\title{
A DESCRIPTIVE SURVEY OF ATTITUDES TOWARD ART CLASSES
}

\section{Marge Stell}

The Descriptive Survey

I did a comparison survey of attitudes about art classroom management, grading policies and personal attitudes about individual art work. I compared the combination 5 th/6th grades class room and the Intermediate Family School class at an elementary school.

The 5 th/6th grades class has 24 students who are of low academic ability. No one in the class is reading within a year and a half of grade level. There is a high incidence of children whose families move from place to place in the city. They are considered neighborhood children even if they don't 1 ive in the school neighborhood all of the academic year. They attend the school in order to maintain stability.

The Intermediate Family School class has 25 students who are preselected for attendence in Family School. They range from 3rd to 6 th grade. Family School is an alternative school program. Parents take an active part in working as volunteers on special projects in school. They have a social extention beyond school time which includes camping trips, field trips, covered dish suppers, and a parent committee that meets periodically with the instructor. The children are all bright and/or strongly independent in their ability to work on academics without directed supervision. They perform much better in an unstructured, open atmosphere. They have demonstrated the desire and ability to pursue academic work according to their own needs and the personal drive to go on beyond the usual grade limits in any given academic area. 


\section{Marge Stell}

The 5 th/6th grades class operates in a very structured class room situation. They can't handle change in routine easily. Substitute teachers upset them. New problems or different or exciting plans for the day tend to cause a great deal of disruption in class. They receive regular report cards. They often are disciplined with isolation in the Principal's office, paddling, and detention time after school. They frequently have fights, squabble, 1 ie, cheat, steal. They also share and have good friendships and do try to get their work done. They do not conduct themselves in a classroom in any usual sense of quiet, order, organization, respect or reticence.

Family School children do not ever receive report cards. They get written narrative reports on their performances and form contracts with the instructor for a given amount of academic work they will accomplish within a day or a week. They operate a democratic classroom which includes a morning meeting to set the plans for the day. There are no desks in rows. The room is similar to a big, rambling house with many interest areas in which to work. The discipline situations are resolved in individual conferences with the instructor, or in small groups, or by parent conferences. Occasionally, a student is denied a pleasurable activity until he or she has corrected a deficiency in some area.

I often have marveled at the difference between these two groups. There are several neighborhood children in Family School. I al so have noticed that some Family School children pay attention to the regular report cards received by the other classes. I, therefore, asked the question about report cards to see if they might indicate that they wanted a letter grade evaluation at least some of the time. In addition, 


\section{Marge Stell}

I wanted to know if the 5 th/6th class would like a more open and free environment for art class.

I was interested in how the 5 th/6th class felt about lecture/demonstration presentations in art class. I was sure I already knew what Family School students thought of that method of instruction.

I was curious about the attitudes of both groups toward their own work--whether they felt success and pleasure in their work. I also wondered if they considered themselves as successful in art class.

Some questions were constructed to elicit their general views of curriculum: whether the students realized there is a basic design in the system for art classes; whether the students felt there was a tie in with other subject areas; whether the students considered art to be necessary for their educational development.

I could have asked just "yes/no" questions, but I added "sometimes" and "don't know" response categories after seeing Bi11 Cosby demonstrate kids' reactions to "yes/no" answers. He said "sometimes" means "yes", but kids would rather say "sometimes" than go out on a limb and state finally and absolutely "yes". Also, "I don't know" usually means "yes" or at least some knowledge of the situation, but the kids don't want to incriminate themselves so they will evade an answer if possible. The questionnaire was highly structured in any case, but may be evaluated by adding all "sometimes" responses to the "yes" percents. However, the high percentage of "don't know" responses to the question about School District curriculum guides was an honest "I don't know" response. Therefore, I don't think the "don't know" responses should be added to the "yes" category. They need to be kept in a separate coding. Some students in Family School 


\section{Marge Stell}

indicated on their paper that this was the same as a "no" comment for them.

The survey was fun to do and had some surprises. The classroom teachers administered the questionnaires. The 5 th/6th grades teacher read it aloud to her students. The Family School instructor let his students complete the questionnaires on their own time. They all were told they did not need to sign their names. Most Family School students did sign them, but some did not. A11 5th/6th students signed their names. The 5 th/6th students were very vocal and opinionated about their answers and appeared to enjoy the activity. The Family School students were much more blase about it, but all of them responded which surprised me.

The percentages of responses in each category for the two groups are indicated directly under the individual questions. In some instances, such as the high percentages of yes responses to students' choosing their art projects and materials, there is considerable agreement between the Family School class and the 5 th $/ 6$ th grades class. On other questions, there is more disagreement; the desirability of quiet art classes is an example.

This type of research is time consuming. I used a calculator to compute percentages. I decided I would rather survey two whole classes than just two or three students in each group. I wanted a more complete picture. The students are so unique that two or three from each class might not represent the entire groups.

I am glad so many signed their names because their responses are more valuable to me than the percentages of the whole group. The percentages seem to support the premise of Family School that their students do not 


\section{Marge Stell}

need letter grades. The answers to the questionnaire also alerted me to the fact that students in both groups do want some feedback from the instructor on their art work. Comments were desired.

ART CLASS DESCRIPTIVE SURVEY - 21 Family School respondents

$235 / 6$ Grade Respondents

Circle your answer

1. DO YOU THINK ART SHOULD BE A REQUIRED COURSE IN ELEMENTARY SCHOOL?

$\begin{array}{lllcc}\text { F.S. } & 30 \% & 40 \% & 21 \% & 4 \% \\ & \text { yes } & \text { no } & \text { sometimes } & \text { don't know } \\ 5 / 6 & 57 \% & 19 \% & 14 \% & 9 \%\end{array}$

2. DO YOU THINK ART LESSONS HELP YOU IN ANY OTHER SCHOOL WORK?
F.S.
$47 \%$
yes
$26 \%$
no
$17 \%$
sometimes
$23 \%$
$47 \%$
$8 \%$
don't know
$5 / 6$
$28 \%$
$0 \%$

3. HAS ART CLASS EVER BEEN THE KIND OF CLASS YOU WERE EXPECTING IT TO BE?

3. HAS ART CLASS EVER BEEN THE KIND OF CLASS YOU WERE EXPECTING IT TO BE?

$\begin{array}{lllcc}\text { F.S. } & 26 \% & 34 \% & 39 \% & 0 \% \\ 5 / 6 & \text { yes } & \text { no } & \text { sometimes } & \text { don't know } \\ 57 \% & 23 \% & 28 \% & 0 \%\end{array}$

4. DO YOU THINK PEOPLE SHOULD WORK QUIETLY IN ART CLASS?
F.S.
$39 \%$
yes
$26 \%$
no - someti
$5 / 6$
$76 \%$
$30 \%$
somet imes
$14 \%$
$4 \%$
don't know

5. DO YOU THINK PEOPLE SHOULD HAVE ASSIGNED SEATS IN ART CLASS?
F.S.
$4 \%$
$5 / 6$
yes
$19 \%$
$86 \%$
no
sometimes
$66 \% \quad 9 \%$
$0 \%$
don' $t$ know
$4 \%$

6. DO YOU LIKE QUIET ART CLASSES?

$\begin{array}{lllcc}\text { F.S. } & 43 \% & 26 \% & 26 \% & 4 \% \\ 5 / 6 & \text { yes } & \text { no } & \text { sometimes } & \text { don't know } \\ 50 \% & 0 \% & 14 \% & 4 \%\end{array}$

7. DO YOU LIKE AN ART LAB TYPE OF CLASS - FOR EXAMPLE - STUDENTS WORKING ON WHATEVER PROJECT THEY WANT TO WORK ON USING WHATEVER MATERIALS THEY WANT TO USE?

$\begin{array}{llccc}\text { F.S. } & 78 \% & 0 \% & 8 \% & 13 \% \\ 5 / 6 & \text { yes } & \text { no } & \text { sometimes } & \text { don't know } \\ & 71 \% & 4 \% & 23 \% & 0 \%\end{array}$




\section{Marge Stell}

8. DO YOU THINK STUDENTS SHOULD BE WORKING ON ART WORK ALL THE TIME WHEN IN ART CLASS?

$\begin{array}{ccccc}\text { F.S. } & 34 \% & 39 \% & 13 \% & 13 \% \\ & \text { yes } & \text { no } & \text { sometimes } & \text { don't know } \\ 5 / 6 & 38 \% & 33 \% & 23 \% & 4 \%\end{array}$

9. DO YOU THINK IT'S NECESSARY TO HAVE ASSIGNED WORK IN ART CLASS?

$\begin{array}{crccc}\text { F.S. } & 0 \% & 86 \% & 13 \% & 0 \% \\ 5 / 6 & \text { yes } & \text { no } & \text { sometimes } & \text { don't know } \\ & 28 \% & 23 \% & 37 \% & 9 \%\end{array}$

10. DO YOU THINK STUDENTS SHOULD CHOOSE WHAT ART AREAS THEY WILL STUDY?

$\begin{array}{llccc}\text { F.S. } & 52 \% & 8 \% & 34 \% & 4 \% \\ & \text { yes } & \text { no } & \text { somet imes } & \text { don't know } \\ 5 / 6 & 42 \% & 28 \% & 28 \% & 0 \%\end{array}$

11. DO YOU THINK THE SCHOOL DISTRICT HAS AN ART STUDY PROGRAM THAT ALL STUDENTS ARE EXPECTED TO KNOW?

$\begin{array}{ccccc}\text { F.S. } & 13 \% & 8 \% & 0 \% & 78 \% \\ & \text { yes } & \text { no } & \text { sometimes } & \text { don't know } \\ 5 / 6 & 33 \% & 19 \% & 19 \% & 28 \%\end{array}$

12. DO YOU THINK YOU HAVE LEARNED ANYTHING ABOUT ART IN ART CLASS?

$\begin{array}{ccccc}\text { F.S. } & 56 \% & 17 \% & 26 \% & 0 \% \\ 5 / 6 & \text { yes } & \text { no } & \text { sometimes } & \text { don't know } \\ & 71 \% & 0 \% & 23 \% & 4 \%\end{array}$

13. DO YOU THINK GRADES ARE NECESSARY IN ART CLASS?

$\begin{array}{lrccc}\text { F.S. } & 0 \% & 91 \% & 8 \% & 0 \% \\ 5 / 6 & \text { yes } & \text { no } & \text { sometimes } & \text { don't know } \\ & 80 \% & 4 \% & 14 \% & 0 \%\end{array}$

14. DO YOU WANT A GRADE ON YOUR ART WORK?

$\begin{array}{lllcc}\text { F.S. } & 26 \% & 39 \% & 26 \% & 8 \% \\ 5 / 6 & \text { yes } & \text { no } & \text { sometimes } & \text { don't know } \\ 516 & 61 \% & 0 \% & 28 \% & 9 \%\end{array}$

15. DO YOU WANT A TEACHER TO WRITE COMMENTS ABOUT YOUR ART WORK?
F.S.
$56 \%$
$30 \%$
$13 \%$
$0 \%$
$5 / 6$
yes
no
sometimes
don't know
$0 \% \quad 23 \% \quad 0 \%$

16. DO YOU THINK EVERY STUDENT SHOULD HAVE THEIR ART WORK DISPLAYED?

$\begin{array}{lrccc}\text { F.S. } & 8 \% & 39 \% & 47 \% & 4 \% \\ & \text { yes } & \text { no } & \text { somet imes } & \text { don't know } \\ 5 / 6 & 38 \% & 19 \% & 38 \% & 4 \%\end{array}$

17. DO YOU THINK SOME PEOPLE ARE BETTER ARTISTS THAN OTHERS?
F.S.
$65 \%$
$5 / 6$
yes
$4 \% \quad 30 \%$
no sometimes
$9 \% \quad 4 \%$
$0 \%$
don't know
$4 \%$ 


\section{Marge Stell}

18. DO YOU THINK ART ABILITY IS LEARNED?

$\begin{array}{ccccc}\text { F.S. } & 34 \% & 17 \% & 43 \% & 4 \% \\ 5 / 6 & \text { yes } & \text { no } & \text { sometimes } & \text { don't know } \\ 57 \% & 19 \% & 19 \% & 4 \%\end{array}$

19. DO YOU THINK SOME PEOPLE ARE BORN BETTER ARTISTS THAN OTHERS?

$\begin{array}{ccccc}\text { F.S. } & 47 \% & 39 \% & 13 \% & 0 \% \\ & \text { yes } & \text { no } & \text { somet imes } & \text { don't know } \\ 5 / 6 & 47 \% & 19 \% & 19 \% & 14 \%\end{array}$

20. DO YOU THINK YOU DO WELL IN ART WORK?

$\begin{array}{ccccc}\text { F.S. } & 34 \% & 8 \% & 52 \% & 4 \% \\ & \text { yes } & \text { no } & \text { sometimes } & \text { don't know } \\ 5 / 6 & 38 \% & 19 \% & 38 \% & 4 \%\end{array}$

21. DOES DOING ART WORK GIVE YOU PLEASURE?

$\begin{array}{ccccc}\text { F.S. } & 17 \% & 4 \% & 78 \% & 0 \% \\ & \text { yes } & \text { no } & \text { sometimes } & \text { don't know } \\ 5 / 6 & 52 \% & 9 \% & 33 \% & 4 \%\end{array}$

